\title{
Amakosikazi: Undervalued Figures in Zulu History
}

\author{
Caellagh Morrissey, History and International Studies*
}

\begin{abstract}
Extractive European Imperial forces often justified colonization as a crusade, bringing civilization to a timeless and barbaric continent. One way of validating this justification was to create a narrative, or a history of the people being colonized, which allowed a European audience to excuse invasions as an attempt to resituate savage peoples away from their own barbaric past. This paper examines the Zulu Kingdom in southeastern Africa that rose to power after 1816 under the rule of Shaka KaSenzangakona, a controversial and powerful figure whose military and political innovations consolidated loosely affiliated peoples into a more centralized and militarized society. This article examines historical record of Zulu history to identify women who articulated agency in the political and religious spheres of Zulu history. This paper aims to contribute to decolonizing the past by supporting an argument expanding recognition of elite women in Zulu history. This will be accomplished through identifying and examining the roles of specific elite members of the royal family from what is generally considered the rise of the Zulu nation in 1816 until its eventual fall in the early twentieth century. The paper will first detail limitations of sources and explain current academic understanding, and then will progress to an analysis of specific figures in chronological order.
\end{abstract}

\section{INTRODUCTION}

Often there were no written histories in pre-colonial Sub-Saharan Africa. Histories were remembered orally, but not written down, so stories written by adventurers, colonial officials, and missionaries perpetuated many of the stereotypes and assumptions that Europeans in Africa held in early written histories. No alternative written history existed to counter or correct from an African viewpoint. Researchers working on pre-colonial and early colonial African history must therefore rely on written documents produced in a highly biased context. Such narratives, while problematic in themselves, can still permit us to reassess the peoples they depict with a more nuanced sensitivity to the fluidity of gender roles, and a more nuanced awareness of the nature of political power structures.

Under leadership of Shaka, his brothers and their progeny, the Zulu Kingdom posed the most widely recognized threat to settler expansion and colonial conquest in the hundred years following its rise. The fortunes of the Zulu kingdom closely correlated to the Zulu royal family, and while the kings in this family have been studied extensively, the women have been largely ignored in historical texts. European officers, explorers, and historians conveyed an image of the

${ }^{*}$ Caellagh Morrissey is a senior studying History and International Studies with a minor in African Studies from Boulder Colorado. She is interested primarily in issues of development and the constant revision and multiplication of historical narratives and conceptualizations. In her free time, Caellagh is on the University of Oregon club Rowing team and she enjoy backpacking, cooking experimental foods, and drinking lots of tea. 
Zulu as violently patriarchal, pagan savages to Victorian English Society. This image was informed by their own patriarchy and colonial aims, which sought to validate their exploits to British society. It did not tend to recognition of female agency, and thus often overlooks it, except as an anomalous or unnatural phenomenon. These elite women and collective groups of women have been portrayed as objects of history by English historians who typified Zulu society as a strict patriarchy. However, Zulu elite women did react to external intervention and shaped it alongside their male counterparts.

\section{HISTORIOGRAPHY AND SOURCES}

When examining primary sources, it is always necessary to first assess the point of view in which any particular piece was written. The evidence put forth in this paper draws primarily on the James Stuart Archive of Oral Histories ( 5 volumes), The Diary of Henry Francis Fynn, praise poems collected by James Stuart and translated in A. T. Cope's Izibongo, and historical accounts written in the early twentieth century. Each of these sources has its strengths and weaknesses, and historians must assess each in turn.

The James Stuart Archive of Oral Histories is a collection of interview materials gathered by the Colonial magistrate and commissioner James Stuart between 1894 and 1924, during his travels and work in British-annexed Zululand. While a much richer collection than is available for many other time periods and peoples, it cannot be accepted as pure fact. Stuart was severely biased in his views, which exaggerate and minimize the realities of Zulu life to conform to his preconceived ideas about Zulu history or strengthen the credibility of his or his government's political actions. ${ }^{1}$ In addition, his informants were often in a compromising position. An imperial official in an expanding British Empire, Stuart effectively usurped the power of the very men he was interviewing. He had no interest in interviewing elite Zulu women, instead he gleaned information about Zulu culture and history from a very select portion of the population under conditions of high stress.

Stuart also relies heavily on stories and views of earlier explorers such as Henry Francis Fynn. Fynn was a trader and government official whose exploits were published for a Victorian English audience. His stories were deliberately crafted to be interesting, but not necessarily to be truthful. Fynn's diary itself did not appear until after his death, indicating a still further removal from the evidence and time period it is intended to represent. However, despite its faults it is a valuable resource considering the lack of other contemporary written accounts.

In addition to these sources, this paper relies on early scholastic interpretations of Zulu History. One historian, Alfred Bryant, wrote on collective identities of people in South Africa's pre-colonial past. In his obituary, his greatest contribution was considered to be his ZuluEnglish dictionary. However, as a priest in Zulu territory he was exposed to oral histories that informed some of his historical texts. ${ }^{2}$ These texts were well respected by South African

\footnotetext{
${ }^{1}$ J. Cobbing, "A Tainted Well. The Objectives, Historical Fantasies and Working Methods of James Stuart," The Journal of Natal and Zulu History 6 (1988): 115-154.

2 D. Mck. Malcolm, “Obituary," African Studies 12, no. 3 (1953): 131-132.
} 
historians through the late 1980's. However, work by Carolyn Hamilton and John Wright, two historians concerned with South Africa, reexamines Bryant's works and finds that little was based on pre-existing literature. They conclude that much of his work was his particular interpretation of scrappy and conflicting information from conversations with various unnamed Africans. ${ }^{3}$

Later biographies of nineteenth century Zulu rulers can also offer valuable information about the lives of elite Zulu women. Like Bryant's histories, these biographies are limited in that their information is often unverified, the writers were white and had variable exposure to Zulu life, and none of the subjects were directly interviewed. These stories were appropriations at best, however they still offer information about the Zulu royal household from a different perspective and include details that are not obvious in official documentation or the contemporary histories.

Stuart also collected contemporary praise poems in his journals. These poems (isibongo) acted as a storehouse of social and cultural memory within Zulu society. The poems are useful in that they offer a glimpse of Zulu history from the perspective and in the words of Zulu people themselves. However, they are also difficult to analyze given that metaphors have been since lost to cultural memory. Additionally, isibongo could serve as a forum for political slander, and were often rife with innuendo, and sarcasm. Finally, Stuart's collection of poems was not exhaustive, again coming from a select group of men working with imperial officers.

The historians Sifiso Ndlovu, Jennifer Weir, and Carolyn Hamilton have reexamined depictions of elite Zulu women as a class in primary sources. Their works have shown these women have more important roles than was recognized by South African Historians before 1995. 4 Hamilton established that Amakosikazi (elite women) are now thought to have held a role in political life, controlled amakhanda (regimental towns), and even led amabutho (military regiments). Weir suggests the relationships between early kings and a few select amakosikazi, and Sifiso establishes women's rule as a topic that must be further examined. These sources suggest that female participation in Zulu political life was more nuanced and fluid than earlier histories represented. The following analysis will expand and build on the premises put forth by these historians, by examining specific women as case studies to suggest how the role of the amakosikazi changed over time, a subject that has been suggested but not yet studied.

\footnotetext{
${ }^{3}$ Carolyn Hamilton, "Backstory, Biography and the Life of the James Stuart Archive," History in Africa 38 , no. 1 (2011): 333-335. Carolyn Hamilton, Terrific Majesty: The Powers of Shaka Zulu and the Limits of Historical Invention (Cambridge: Harvard University Press, 1998), 59-71; John Wright, “A.T. Bryant and the 'Lala'," Journal of Southern African Studies 38, no. 2 (2012): 355-368.

${ }^{4}$ Sifiso Ndlovu, “A Reassessment of Women's Power in the Zulu Kingdom," in Zulu Identities: Being Zulu, Past and Present, ed. Benedict Carton, John Laband, and Jabulani Sithole (New York: Columbia University Press, 2009 ), 112. Jennifer Weir, "I Shall Need to Use Her to Rule: The Power of 'Royal' Zulu Women in Pre-Colonial Zululand,” South African Historical Journal 43 (2000): 10.
} 


\section{MNKABAYI: INDIVIDUAL WOMEN WITH POLITICAL INFLUENCE}

The first important narrative to examine is that of Mnkabayi. She was the head wife of the father of Shaka kaSenzangakhona (king during the expansion and initial rise of the Zulu Kingdom), and is one of the best-recognized examples of individual elite women wielding actual positions of political power in Zulu society. She played an active part in political life in KwaZulu, negotiating and plotting during changes in rulers on at least two occasions. Bryant labeled her a "tigress" and a "freelancer" in his historical writing. ${ }^{5}$ His word choice suggests that Mnkabayi was a sort of political maverick. However, his narrative is not the only one. South African feminists argue that elite women associated with the ruling Zulu houses "were actually part of the system of leadership before, during, and after Shaka's reign." ${ }^{6}$ It was within this very same system of leadership that Mnkabayi was able to gain legitimacy and control within the Zulu political system. In fact she did hold power before, during, and after Shaka's reign.

Before Shaka rose to power Mnkabayi might have held the position of interim king in the immediate aftermath of Jama and Senzangakona, the two Zulu kings before Shaka. Senzangakona was her husband and Shaka's father. One of James Stuart's informants' states, "that Mkabayi ruled a little after Senzangakona's death."7 If Mnkabayi ruled, even in the sense of being in charge of daily activities, before Shaka was named king, then at least one elite woman held the highest position of authority within Zulu society for a brief point in time early in Zulu history. Another of Stuart's informants states, "Senzangakona had no one who stood armed by his grave as his successor...for when Tshaka got up, people accepted him without a fight...It is probable then that Tshaka was offered the position of king." 8 Here we have Shaka passively being 'offered' the position. It may well have been Mnkabayi who offered it to him. 9

If Mnkabayi did indeed place Shaka in power, she did not leave him there for long. John Laband, one of the most meticulous Zulu historians whose research is still considered amongst the most reliable on the topic, discusses Mnkabayi's role in Shaka's assassination in 1828 in The Rise and Fall of the Zulu Nation. Shaka was murdered by several of his brothers, including Dingane who would take his place as king and rule for the next twelve years. Laband refers to Mnkabayi as the "formidable king-making aunt," for her role in Shaka's downfall, during which she "encouraged them [Shaka's assassinators] in their resolve."10 Analysis of recorded isibongo (praise poem) indicates that Mnkabayi not only incited Dingane and his fellows to murder Shaka, but was also involved in vindicating their actions and supporting Dingane in his rise to the throne. Carolyn Hamilton specifically cites a poem recorded by the contemporary J. T. Arbousset which states, "Death-defilement antidotes were eaten, within; They were eaten by

\footnotetext{
${ }^{5}$ Alfred T. Bryant, Olden Times in Zululand and Natal (New York: 1929), 41.

${ }^{6}$ Jennifer Weir,"I Shall Need to Use Her to Rule: The Power of 'Royal' Zulu Women in Pre-Colonial Zululand," South

African Historical Journal 43 (2000): 10.

7 Ibid., 5 .

${ }^{8}$ JSA I: 199.

${ }^{9}$ Weir, "I Shall Need to Use Her to Rule," 7.

${ }^{10}$ John Laband, The Rise \& Fall of the Zulu Nation (London: Arms and Armour Press, 1997), xiii.
} 
Mmama and Mnkabayi."11 This statement refers to how Mnkabayi and her twin sister Mmamma absolved Dingane of his fault for assassinating Shaka. While such an act would normally have rendered him ineligible for succession, approval of the two older sisters allowed him to take his place as king.

Mnkabayi was not only an amakosikazi who was in charge of organizing and coordinating the barracks and regiments responsible for Zulu power. She was also an active participant in Zulu political life, taking direct rule in some instances and in others heavily influencing the actions of the men participating in the actual political battles. She may not have always been featured as a major player in the narratives of South African historians and travel writers, but she clearly exhibited significant influence in a political world that has been labeled as male dominated. The legitimacy of labeling Zulu political and religious authority as an exclusively male arena is further contested by the existence of praise poems which refer to Mnkabayi using the praise name "Soqili." ${ }^{12}$ A.T. Cope, writer of Izibongo Zulu Praise Poems published in 1968, called the use of what he considered a male praise name for a female figure, "significant as a reflection of character."13 Norma Masuku argues that the use of this name may have been a reflection of the strong character through which Mnkabayi exhibited "the same cardinal virtues as men"14. However, this statement assumes that because Mnkabayi's praise-name referred to her as using a name most commonly used for powerful men, she must have taken on the role of one. This statement could also be interpreted to suggest instead that the praise-name indicates a level of respect as well as a position of authority that could be afforded to particularly praiseworthy or politically involved amakosikazi during this time period. While it may also indicate strength of character and the qualities as an influential political payer that Mnkabayi possessed, to discount this as an indicator of personal character is simplistic. Whether or not the praise name is for men alone, during this important period of formation of the Zulu nation at least one powerful elite woman of the royal household actively altered and affected that formation politically.

\section{NANDI: THE ROLE OF ELITE WOMEN IN SUCCESSION AND PATRONAGE}

Mnkabayi is not the only significant female who is given the praise-name Soqili. Nandi, Shaka's own mother, is also described with this title. ${ }^{15}$ Nandi, too, is seen as a particularly strong example of a royal woman with extremely strong characteristics that were even labeled as manly by European observers. She certainly was able to influence Shaka's childhood in ways that Senzangakona, Shaka's father, could not. As a young boy Shaka lived, for a time, with the Langeni chiefly house, the house of his mother. ${ }^{16}$ Some stories indicate that they had to leave in

\footnotetext{
${ }^{11}$ Carolyn Hamilton, Terrific Majesty: The Powers of Shaka Zulu and the Limits of Historical Invention, (Cambridge, Mass: Harvard University Press, 1998), 108.

${ }^{12}$ A.T. Cope, Ed. Izibongo: Zulu praise-poems (Oxford: Clarendon P, 1968), 172.

13 Ibid., 172.

${ }^{14}$ Norma Masuku, "The depiction of Mkabayi: A Review of her praise poem," South African Journal of African

Language 29, no. 2 (2009): 121-130.

${ }^{15}$ Cope, Izibongo, 173.

${ }^{16}$ JSA IV: 40.
} 
order to avoid being killed by Senzangakhona's other wives. ${ }^{17}$ Other versions describe Nandi as fleeing from Senzangakhona. Regardless of the true situation, all agree that Nandi's family acted as a support system on which Shaka leaned on during his exile, and became important political allies. Without Nandi's family connections Shaka would never have had the support he needed to eventually stage his rise to power.

Sean Hanretta has examined some of the ways in which royal wives might pose a threat to male inheritance. He puts forth that "A woman's power as advocate for her son could, and did, threaten a husband's control over the reproduction of the homestead." 18 A potential heir would need to rely on his mother's family for support in rivalries with other potential heirs from other mothers. If one family wanted to intervene and potentially usurp the power from another family, they might give a wife to the induna (headman) in the hope that she would bear a son who could champion their claim to the power. Adam Kuper notes that "a chief who dispatched a wife to a rival was making a political intervention, aspiring to control the succession into the chiefly house into which the princess was introduced." 19 In the Stuart archive, there are stories that relate the fall of great kings to the conniving actions of a wife intentionally causing disruption to further her family's interests. ${ }^{20}$

An important female population within the royal compound was the umndlunkulu (royal handmaidens). ${ }^{21}$ Those women were adopted into the isigodhlo (royal compound) as adjuncts. These women could be 'gifted' out to various induna (headmen), however there are instances in which the headmen who received these women were required to pay the lobola (bride price) back to the royal family. As such, the umndlunkulu became a source of wealth for whomever they belonged to. They also maintained their connections with the isigodhlo (royal compound) after being sent out in marriage. In this way, they could also act as informants and a symbol of the royal family in a more remote area, further solidifying the control of the region by the royal family. ${ }^{22}$

Nandi was important in Shaka's later life because she served as one of the keepers of the umndlunkulu (handmaidens). In addition, her status as Shaka's mother put her in a position of authority in the women's portion of the isigodhlo (royal compound). This compound was considered by Bryant and others as a private harem for Shaka and the other kings, but Hanretta has shown that "much more than harems of the [chief or] king; they were focal points and sources of regal patronage" because of the possibility of using these women to gain access and favor with distant induna (headmen). ${ }^{23}$ However, she and her son did not always have the same intentions. Shaka allegedly killed Nandi for hiding an heir from him, which threatened his

\footnotetext{
${ }^{17}$ Ibid., 39.

${ }^{18}$ Sean Hanretta, "Women, Marginality and the Zulu State," The Journal of African History 39, no.3 (1998): 391.

${ }^{19}$ Adam Kuper, "The 'House' and Zulu Political Structure in the Nineteenth Century." The Journal of African History 34, no. 3 (1993): 484. Adam Kuper, "Symbolic Dimensions of the Southern Bantu Homestead," Africa: Journal of the International African Institute 50, no. 1 (1980): 8-23.

${ }^{20}$ JSAII: 216; JSAI: 176-7; JSA III: 232.

${ }^{21}$ Hanretta, "Women, Marginality, and the Zulu State," 407-409.

${ }^{22}$ Control over this process by the amakosikazi is referred to earlier in this paper as an example of female agency and participation in political processes (pg. 9)

${ }^{23}$ Ndlovu, “A Reassessment of Women's Power," 113.
} 
political agenda..24 Jennifer Weir argues Shaka engaged in ritual 'celibacy' in order to "focus power on himself" and "address potential threats" or heirs who may contend for power and decentralize the state. ${ }^{25}$ If Shaka had an heir then this child may have grown up to challenge the throne. Thus, any attempts to keep an heir would effectively undermine his authority. However, in one account Shaka discovered Nandi nursing a small child and demanded to know "Where does it come from?" To which Nandi cheekily responds, "Don't you have a penis then?" 26 Shaka, in the story, replies by rashly murdering his own mother. Nandi's actions can be read as an example of an attempt to enact her own will upon her son, and Shaka's response would indicate that from his position of political authority in a centralizing state, the threat of a potential harbored heir was great enough to kill the child, and even his own mother to ensure that it would never happen again. It is important to also note the possibility that this story is fabrication. By painting Shaka as a matricidal ruler his rivals could cut away at his credibility, or indeed the legitimacy of his newly consolidated house.

Even if he did kill his mother, Shaka still tried to decrease the disruption this created by having a lavish funeral. Sean Hanretta has shown that "the connection with the natural world and thereby with the spirit world enabled some women to become powerful diviners, and opened roles for wives as chief mourners and potential practitioners of sorcery within the homestead." ${ }^{27}$ If Shaka killed Nandi, a connection to the divine and his ancestry, he would have had to find a way to resolve the disruption made by killing an important link to the ancestors. He did this through a funeral ceremony, which emphasized coming together as a nation and consolidating support for the Zulu Royal family. Fynn's account of Nandi's funeral involved mass mobilization and grieving. ${ }^{28}$ Jennifer Weir analyzes that the funeral was "more extravagant than those of male chiefs" and relates it to an "ihlambo or purification ceremony" that consisted of a cattle raid instead of the traditional hunt. ${ }^{29}$ While some might explain this as an excuse on the part of Shaka to raid for cattle, it can more convincingly be read as an attempt to sanctify Nandi's death and bring peace and balance after the loss of an important religious figure. In addition, Fynn's account of Mntaniya's funeral ceremony also showed examples of mourning on a national scale, bringing the surrounding peoples together in reverence of a significant female figure. $3^{\circ}$ Shaka may have used these ceremonies to consolidate his power and bring support to the Zulu Royal household.

Nandi was certainly a powerful female figure and there are examples of her active attempts to shape Zulu politics through her influence on her son and through her family ties, which supported her and Shaka through his childhood. However, it is clear that this was not unconditional influence, and when pushed to extremes Shaka still had the utmost authority. Despite this, both Nandi and Mntaniya had funerals, which were used as tools to consolidate the

\footnotetext{
${ }^{24}$ JSA V, 35 .

${ }^{25}$ Weir, "I Shall Need to Use Her to Rule," 19.

${ }^{26}$ JSA V, 35.

${ }^{27}$ Hanretta, "Women, Marginality and the Zulu State," 392.

${ }^{28}$ Fynn, Diary, 131-133.

${ }^{29}$ Jennifer Weir, "Chiefly Women and Women's Leadership in Pre-Colonial South Africa," in Women in South African History ed. Nomboniso Gasa (Cape Town: HSRC Press, 2007), 14; JSA V: 35. (italics are mine)

${ }^{30}$ Fynn, Diary, 121; Ibid., 131-133; JSA I: 307, 337; JSA IV: 292-3.
} 
importance of not only Shaka, but his female relatives as well, indicating that the power lay in the family itself as opposed to a singular powerful male.

\section{INCREASING CHALLENGES TO FEMALE POWER}

Nandi may have been powerful and important, but she was not the most powerful or important of Senzangakhona's wives before his death. Nandi held only a minor position in a hierarchy of wives, which dictated which wife had which privileges, and controlled what part of the household and whose children would inherit the most. In the Zulu Royal house this was particularly important because these women not only held powerful positions in the home, but were also in charge of particular amakhanda (army barracks), or amabutho (military regiments). ${ }^{31}$ Therefore, the politics of amakosikazi (elite women) in the Zulu household had repercussions on a massive nation-wide scale. The army acted as the source of unity and wealth, so controlling the barracks and regiments would have been an influential position. During the organization of a centralized Zulu nation, Shaka, and later Dingane, maintained a system in which elite women who were not a direct threat to the throne acted as symbols of central authority for the kings. ${ }^{32}$ They acted as judicial authorities (in one documented instance ordering the death of Shaka's brother), organized militarily regiments, and as we have seen with Nandi and Mnkabayi, actively entered into Zulu politics. 33 Hanretta argues that the role of women in amakhanda (army barracks) was new to Zulu society and was "the most obvious effect" of a new system of organization, which acted as a "subtle disruption of gender duality" within the state. ${ }^{34}$ However, this new system seems to point towards fluidity of gender roles and collaboration by members of the Zulu Royal household, both male and female, to organize a new more consolidated political and religious system within the region. 35

One effect of women participating in this effort to reorganize the state was the way in which politics of the home were magnified onto a national scale in the royal household. Bhibhi was a sister-wife to Nandi, whose interactions with Shaka and other rulers indicate how power struggles within the women's realm had repercussions, or held influence, in the greater political arena. One of Stuart's informants provides a tale of Shaka's rise to power within the Zulu chiefdom that sheds some light on Bhibhi's interactions with the males in her household. In the story, Senzangakona must identify Shaka, his son who he had not seen in many years, to prove that they are related and indicate Shaka's legitimacy and recognition by his father. Afterwards, Shaka is called by the amakosikazi (elite women) in his father's household. These women, referred to as "Tshaka's mothers", "called him" and "kissed him."36 However, Bhibhi alone refused to interact with Shaka. "This woman, who was an injinjikazi, and liked by the king, did

\footnotetext{
${ }^{31}$ Kuper, "Symbolic Dimensions of the Southern Bantu Homestead," 23.

32 Weir, "I Shall Need to Use Her to Rule," 14; Hanretta, "Women, Marginality and the Zulu State," 398.

${ }^{33}$ JSA IV: 292.

${ }^{34}$ Hanretta, "Women, Marginality and the Zulu State," 398.

${ }^{35}$ Hanretta writes: "New social positions that opened for or were forced upon women in the early nineteenth century produced overlapping systems for defining worth in relation to men, and created new strategies for increasing personal power and status." Ibid., 414-415.

${ }^{36}$ JSA IV: 122.
} 
not kiss him, but simply looked at him." 37 The disapproval by Bhibhi was notable to the observer as an indication that she did not agree with her husband. This kind of disapproval, even from just one inkosikazi (elite woman) could hurt Shaka's chances of taking his father's place as the induna (headman) of the Zulu prior to their expansion. Shaka needed the approval of the entire household, including the amakosikazi (elite women) in order to be considered more legitimate. To the extent that amakosikazi could publicly legitimize decisions by their male counterparts, women could invalidate decisions as well.

After Shaka's death, Bhibhi remained an important figure. One of Stuart's informants states she became a "woman of great importance." ${ }^{8} 8$ She, like many of Senzangakhona's wives, was in a position of political import as the inkoskazi (elite woman) of a particular ikhanda (barrack). However, while she was immune during Shaka's rule, under Dingane elite women became more and more vulnerable to attacks by elite men of the Zulu Royal household. Dingane's brother (and future rival) Mapande and his allies killed Bhibhi for "impunity" under orders from Dingane.39 "Impunity" suggests that Bhibhi enjoyed too much freedom and may have been considered a threat, especially during a period when many members of the royal household were being killed for opposing Dingane. This indicates that Bhibhi posed a political threat, or at least conceivably might have, to the ruling males just as she posed a threat to Shaka when he met with his father. In an account of her assassination Mpande states, "Let her not be killed. I shall need to use her to rule." 40 This phrase indicates the dependency that male rulers had on their female counterparts in order to maintain order and stability. However, Bhibhi is one example that indicates that this significance and the political role was under attack by individual male rulers seeking to consolidate state power in their own person.

\section{EUROPEAN FORCES IN ZULU POLITICS}

As European forces became more and more powerful within Zulu politics, the power of women began to wane. With the Boers behind him, Mpande relied considerably less on the diplomatic influence of his mother's family to gain the throne, and instead used the military might of an external group. This action reduced the importance of the amakosikazi (elite women) in Zulu politics at a time when at least some of the women who had disagreed with past male rulers were being killed. This compounded with the fact that through the eyes of the conquering parties, women were political minors, reliant on male spokespeople. To a British colonial official, an elite woman was invisible. European officials would not deal directly with the elite women in the Zulu Royal household, as such an action would have gone against what any British official or Trekker would have considered the proper way that gender roles were divided. This limited elite women in their access to diplomatic exchange and European trade and goods. As the British and other external influences began to hold more and more sway over internal Zulu dynamics, women were faced with what T.J. Tallie has defined as an "assault on

\footnotetext{
${ }^{37}$ Ibid, 122.

38 JSA II: 205.

${ }^{39}$ JSA III: 200; JSA II: 206.

40 Ibid.
} 
sociality that did not conform to European heteronormative perceptions." ${ }^{41}$ If women were the focus of a particular paper or article it was often only as the object of perverse marriage practices or agricultural laborers. Emphasis was never on the diplomatic agency these women might have had.

Despite the lack of direct dialogue with elite women, women were no less active in seeking forms of agency in both political and religious arenas within their own culture. Mawa, one of Senzangakhona's sisters, serves as an example of a woman heading a movement and acting in response to a political shift. According to one of Stuart's informants she led a group of people into Natal in 1843 in order to escape the rule of Mpande after the civil war that led to Dingane's death. ${ }^{42}$ According to the account, a large number of people intended to join Mawa in her departure Natal. However, many who intended to follow Mawa were stopped by Mpande's forces, and turned around. Mpande was concerned that "too large a number wanted to accompany her." 43 Mpande then allowed Mawa to depart for Natal, but with a much smaller following.

Stuart's informant states, "I do not know what troubled Mawa so much as to cause her to leave." 44 While this particular informant may not have been able to say, there are some clues that indicate why Mawa may have left for Natal. Mpande had just recently come into power with the help of the Boers. Considering that Dingane had killed members of the royal household, including amakosikazi (elite women) who posed a threat to him after he gained power, it is possible that Mawa was departing to avoid a threat to her life. Natal had recently been annexed by the British, and could have been seen as a potential safe harbor for Mawa and others who had been on the losing side of a bloody civil war. Mawa certainly acted actively in escaping, and was able to lead a group of people into a safer area. While this has not played an important feature in the history of the first Zulu Civil War, it is an instance where royal elite women were able to act independently, although without recognition.

Mawa's exodus was replicated much later during another civil war that erupted in 1856. Another inkosikazi (elite woman) also left for Natal. Monase departed during the second Zulu Civil War following the death of her son Mbuyazi. Mbuyazi and his followers clashed with Cetshwayo and his supporters in a civil war in 1856 over who would be the heir to Mpande. 45 Mbuyazi was killed in the battle of Ndondakusuka. Although Mpande was still alive, his son Cetshwayo effectively secured his position as Mpande's heir and subsequently began exercising considerably more power in Zulu political life. Controversy about Mbuyazi's birth and legitimacy centered around the actions of Monase. Support for her son was a unifying force that drew upon her entire family and ties to further kin or those associated with them. However, unlike in the previous struggle, each side relied on some sort of European support. The English Bishop Colenso and his family supported Mbuyazi and harbored Monase's other son Mkhungu, who

\footnotetext{
${ }^{41}$ T. J. Tallie, "Queering Natal: Settler Logics and the Disruptive Challenge of Zulu Polygamy," Journal of Lesbian and Gay Studies 19, no. 2 (2013): 169.

${ }^{42}$ JSA IV: 120 (However Webb and Wright correct Mawa’s crossing as 1843 not 1842); JSA IV: 138.

${ }^{43}$ JSA IV: 120.

${ }^{44}$ Ibid.

${ }^{45}$ Laband, Rise and Fall, 107-135.
} 
Colenso refers to as "the future king (most probably)." 46 On the other side, Cetshwayo, one of Mpande's other sons, was strongly supported by the Boers. 47 Both sides of the conflict had support from external forces. It seems that by 1856 , relying on the support of kinship ties was no longer enough to ensure success, and while men were the ones in battle, royal women were also active in protecting their families' followers under the banners of their sons.

Nomantshali, one of Mpande's other wives, was a casualty in the struggles of succession. Although not officially in power, Cetshwayo was able to control much of the power after he defeated Mbuyazi, primarily by ensuring that he would not be challenged again. Nomantshali had risen in favor as a new "favorite wife" of Mpande, and had young sons who posed a potential base for a renewed attack on Cetshwayo. ${ }^{8}$ In order to remove this possible threat, Cetshwayo tried to have both sons and mother killed. ${ }^{49}$ Cetshwayo's increase in influence relative to his father is demonstrated by Mpande's inability to retaliate to the murder of his favorite wife. Nomantashali's death can also be compared to Nandi's. When Nomantshali was killed in 1861, Cetshwayo was held less accountable (at least internally) for killing influential women within the Royal household. ${ }^{\circ} \mathrm{He}$ did not need permission from the king as Mpande had when he killed Bhibhi; nor did he feel the need for a lavish nation-wide mourning ceremony the way Shaka had after his mother's death.

By the 1860's there was also a notable absence of strong and powerful individual females who stood out. Although Monase and Nomantshali were each important in their sons' claims to the throne, and were even perhaps active in their pursuit of power, they did not control the same territory, nor did they directly influence politics the ways that Nandi, Mnkabayi or even Bhibhi did. Cetshwayo's relationship with his own wives exemplifies this shift in the power differential within the Zulu household. While none of the wives of Cetshwayo acted as powerfully individually (like Mnkabayi had), they still acted collectively. In one story, Cetshwayo's wife Nhlamule leads her sister wives in shaming Cetshwayo by rejecting a gift from him. ${ }^{51}$ Nhlamule is threatened with her life and then fined for her insolence towards Cetshwayo. Cetshwayo's response to female dissent is considerably more extreme than Mpande's had been considering Mawa and Monase were able to leave Zulu household for Natal in an act of defiance against Mpande. However, this story also indicates that as a collective, the king's wives were still able to communally shame their husband. The kind of communal shaming that Nhlamule took part in was described, and recognized as a tactic of the non-elite women in Zulu society. Stuart's informants describe songs that women would sing to shame their husbands into leaving his favorite wife. ${ }^{2}$ Through rumors, subtle disapproval, and shaming, women were able to exert control over their husbands, even the king.

\footnotetext{
${ }^{46}$ Hamilton, Terrific Majesty, 96.

${ }^{47}$ Laband, Rise and Fall, 352.

${ }^{48}$ JSA IV: 63; JSA III: 106; JSA II: 207.

${ }^{49}$ JSA I: 63.

${ }^{50}$ JSA IV: 78.

${ }^{51}$ JSA IV: 90-91.

52 "Isigqumiselo... This song is sung by women of the kraal when one of their number receives too much attention from the husband...The man, on hearing such singing by the other women, will tie up his mats, leave his favorite, and
} 


\section{ELITE WOMEN DURING ZULU DECLINE}

Cetshwayo had more to deal with than the embarrassment that his wives could cause him. Between 1860 and 1872 he effectively controlled Zulu politics even though Mpande was still alive. He spent much of this time period chasing after Umtonga as a potential threat to the throne and trying to negotiate with expansionist Boers and Britons. In $1872 \mathrm{Mpande}$ passed away and the throne was passed over to Cetshwayo. During the following six years, relations with the British increasingly soured until forces finally clashed in 1878 after an ultimatum set forth by the British was found to be unacceptable. British forces eventually defeated Cetshwayo's army in July of 1879 and he was captured and removed. Zulu territory was never again under a single ruler. The British split Zulu territory then into 13 different "chiefdoms" and tried to rule indirectly through appointed chiefs. This proved ineffective and in 1883 they tried to reinstate Cetshwayo as ruler but were unsuccessful. Cetshwayo died in 1884. His fifteen-year-old son, Dinuzulu, inherited the throne and Cetshwayo's battle against Zibehebu, a former ally who had used Cetshwayo's exile as an excuse to challenge the Zulu royal family. Dinuzulu defeated him with help from the Boers. This concerned the British colonial powers that were in a political struggle with Boer states for control of land in South Africa. Partially in response, the Boers then annexed Zululand in 1887. The official freedom of the Zulu people had ended and despite several instances of coordinated resistance it would never be as strong again.

It is difficult to find much commentary on elite Zulu women in the James Stuart archives after the early 1860s. James Stuart's informants would have been reluctant to comment on ongoing issues. They would also have been reluctant to comment on more recent conflicts between the British and Zulu in an interview with a British official such as Stuart. At this point the biography of Dinuzulu by Binns, who was not contemporary but interviewed Zulu authorities for oral histories, becomes useful. His book provides insightful information about the role some female members of the Zulu royal household played during and after the decline of their kingdom. Nomvimbu, wife of Cetshwayo and the mother of his heir Dinuzulu, can be examined to analyze the changes that occurred in recorded positions of elite women within the Zulu Royal household in this period of reduced materials. The historian Laband described Nomvimbu as Dinuzulu's “capable mother." 53 While Dinuzulu's father was imprisoned after the Anglo-Zulu War, she and her brother were in charge of the young future king. According to Princess Constance Magogo, a descendant of Nomvimbu, "In addition to his uncle Ndabukp another great influence over Dinuzulu during these difficult years was his mother Novimbi Msweli."54 Although Nomvimbu did not hold a particular position that was recognized by the contemporary external observers, and perhaps not even by her own husband, she is described by her descendants as an influential figure. It is difficult to compare this kind of vague influence with the kind of direct power that Mnkabayi had held as an individual, but it does indicate that Nomvimbu was at least still worthy of mention, and could influence her son even if not in the same way that Nandi could. It seems that as a whole, the role of the elite women in the Zulu

go to the other women, i.e. those who are stabbing him with words. He will be unable any longer to eat of the food made by his favorite wife." JSA IV: 39.

${ }^{53}$ Laband, Rise and Fall, 345.

${ }^{54}$ C. T. Binns, Dinuzulu: the Death of the House of Shaka (London: Longmans, 1893), 4. 
household became less specific and had less authority from the rise of the nation in 1816 until its decline into the early twentieth century. There are a few specific instances when these elite women participated in ritual ceremonies, but institutional importance in politics and matters of succession decreased during Mpande’s rule and especially under Cetshwayo. 55

Despite this, women still acted collectively in ways that continued the Zulu state and furthered their own houses. In Dinuzulu's early years, "Too many times in the opening of the years of the 1880 s he was woken by warning shouts before being bundled away to safety by his father's wives and attendants." 56 By protecting the heir to the nation, Cetshwayo's wives acted as guardians of the future of the nation, and actively participated in continuing to bolster their family and royal house's position. While individual women are not implicated here, it is still evident that as a group, amakosikazi were still active in Zulu society even if European observers did not recognize their role.

Elite women did still actively participate in political and social life, in ways that were not possible for their male counterparts. After Cetshwayo's death a group of women, described as his wives, were able to secure the release of Cetshwayo's body to hold a funeral ceremony. ${ }^{57}$ According to Binns:

\begin{abstract}
"The widows of Cetshwayo, angered beyond endurance at the protracted delay in the funeral arrangements of their royal master, took the law into their own hands. On the afternoon of 8 April they set out and made their way in a body to the man who was responsible for their disappointments. Sweeping every obstacle aside they thronged into the Residency demanding the late king's immediate burial. So excited were they, and so violent did they become that Osborn had to beat an ignominious retreat leaving them in full possession of the building...A few hours later official sanction was granted for the removal of the remains to the kraal of Dabulamanzi” 58
\end{abstract}

These women were able to coerce Osborn, a British official, to sanction Cetshwayo's burial. The burial had been forbidden because it required passing through disputed territory, and officials worried it would cause unrest. The elite Zulu men had been unable to convince Osborn to allow this funeral ceremony to take place, but collective action of the elite women succeeded where they had failed. Binns summarizes by saying, "A handful of determined women had succeeded in a task which the combined efforts of the royal brothers had failed to accomplish." 59 Despite this, the official record does not acknowledge the part elite women played in securing Cetshwayo' funeral. Binns states "The official dispatch, though making no mention of this incident, stated tersely, "The Resident Commisioner found it necessary to give his consent to the removal of the remains to a kraal."'60 While the incident may have been interpreted by Osborn and other

\footnotetext{
${ }^{55}$ Weir specifically notes participation in the umkhosi, or first fruits ceremony, by Nomantshali and Songiya, but none of Cetshwayo's wives are implicated in these ceremonies. Weir, "I Shall Need to Use Her to Rule," 17.

${ }^{56}$ Jeff Guy, The View Across the River: Hariette Colenso and the Zulu Struggle Against Imperialism, (Charlottseville: University Press of Virginia, 2002), 95.

${ }^{57}$ Binns, Dinuzulu, 14-15.

58 Ibid.

${ }^{59}$ Binns, Dinuzulu, 14-15.

${ }^{60}$ Ibid., 15.
} 
observers as a bizarre and unprecedented act by a rogue group of women, it demonstrates how the amakosikazi (elite women) still maintained a sense of political, religious, and social power which they could, as a collective, call on when moved to act. These women were not in fact subordinate and passive in their acceptance of the British rule, but resisted just as much as their male counterparts, if with different outlets. Osborn failed to recognize these women as an important and influential population in the territory he oversaw. That a single woman was not named as leading the group indicates that at this point the effectiveness of a single elite female leader had been reduced significantly. However, in their collective actions elite women still played a role in resisting British and Boer occupation even if it went unmentioned in British official documentation.

At this point in time, evidence of amakosikazi (elite women) in Zulu history is most present in praises and music kept alive by royal Zulu women themselves. Princess Constance Magogo, the eldest daughter of Dinuzulu, offers an example of this role after what is considered to be the final "dying breath" of the Zulu Nation when the Maphumulo rebellion was defeated in 1906.61 Princess Magogo lived in a world that was vastly different from that of Nandi four generations prior. She would have grown up under the watchful eye of British officials who kept Dinuzulu close in the hopes that by controlling the Zulu headman, they could better control his people. However, by this point even Dinuzulu, a man, had ceased to wield the same political power that his father had. He was thrown in jail by the British multiple times and was exiled from his people in an attempt to reduce unrest in Zulu society. Magogo was not able to control any land or army regiments like Mnabayi and Bhibhi or even lead large groups of followers like Mawa or Monase. She was designated to a second-class citizenship under colonial laws, and under the extractive British powers her past was rewritten and appropriated by white males who claimed the land of her ancestors. Despite this, Magogo was able to preserve her lineage in a small way. She served as a resource and authority in Zulu music where she was "widely acknowledged as the greatest living authority on the subject." 62 She was considered an important conduit to the past as well as a ritual expert. There is a sense of cultural preservation through Magogo's songs and knowledge of instruments and religious practices, which has been recognized in recordings that immortalize her as the authority of Zulu traditional music. ${ }^{63}$ Indeed, with the increasing importance of the Zulu Royal family emphasized by Zulu nationalism, she may in fact have wielded more authority, in terms of cultural preservation, than even some of her grandmothers. ${ }^{64}$

While it may not have been specifically recorded, Magogo's participation in musical expressions and religious knowledge could speak to a shift in the focus of female agency during

\footnotetext{
${ }^{61}$ Guy, Jeff. The Maphumulo Rebellion: War, Law and Ritual in the Zulu Rebellion (Scotsville: University of KwaZulu-Natal Press, 2005), 6.

${ }^{62}$ David K. Rycroft, "A Royal Account of Music in Zulu Life with Translation, Annotation, and Musical Transcription,” Bulletin of the School of Oriental and African Studies, University of London 38, no. 2 (1975): 353.

${ }^{63}$ Constance Magogo Ka Dinuzulu, ed. Hugh Tracey. "The Zulu Songs of Princess Constance Magogo KaDinuzulu” in Series: Music of Africa Series 37 (Grahamstown: South Africa, International Library of African Music). Also see Cele, T, "Qualities of King Shaka as portrayed in Zulu oral testimony and in Izibongo," South African Journal of African Languages 21, no. 2 (2001): 118-132.

${ }^{64}$ Daphna Golan, Inventing Shaka: Using History in the Construction of Zulu Nationalism (Boulder: Lynne Rienner, 1994), 20-46.
} 
the last half of the $19^{\text {th }}$ century. As the political sphere became increasingly gendered and maledominated, women turned to divination, music, and praise singing as forms of expression through which their understandings could be expressed. 65 While the Zulu nation did not exist as a separate entity, it was still present in the cultural identity of peoples on the east coast of South Africa.

\section{CONCLUSION: ELITE WOMEN REASSESSED}

It is clear that the roles of Zulu women were fluid over the course of the hundred years in question. They held positions of power and actively participated in the creation of various new constructs during the rise of the Zulu nation. As time went by, the powerful positions that these women held were contested and usurped by male rulers trying to dominate and centralize their people. Furthermore, as politics became increasingly linked to relationships with Europeans, or settlers of European decent, who recognized only male elites as important power holders and searched for a singular powerful figure to have control, elite women were pushed even farther to the side. Amakosikazi (elite women) were increasingly targeted during disputes of succession. Through this period the strong female figures present in the Zulu royal household either departed or were killed. Those who remained were still able to affect change and react to oppression through collective action, but this role was much diminished from the kind of power they had once been able to hold, especially in the face of increasing challenges to indigenous ways of life across the region and even across Africa itself. Eventually, as the Zulu nation ceased to be a single entity, the roles of elite women became even more vague. The Zulu household remained a figurehead of indirect rule under the British, but effective autonomy had ceased to be. Still, some elite women remained active in their attempts to preserve their history through music, oral history and customs.

Although Zulu society has historically been presented as a static society with fixed gender roles, closer examination reveals a dynamic culture wherein both men and women's roles fluctuated over time and circumstance. Continuous formation over the course of 100 years shows contributions by both genders and significantly more fluidity and creative agency than has been previously recognized in Zulu society as a whole and by elite women in particular. Much remains to be explored and explained. There are certainly more important amakosikazi (elite women) whose stories are not shared here. However, through careful reconstruction of the influence of the women whose influence has been examined, we can begin to piece together the other half of the history ignored by the traditional narrative.

\section{REFERENCES}

Binns, C. T. Dinuzulu: the Death of the House of Shaka. London: Longmans, 1893.

Bryant, Alfred T. Olden Times in Zululand and Natal. New York: Longmans, 1929.

\footnotetext{
${ }^{65}$ For a full discussion of praise singing and female views on morality, judgement, and history see Eileen Jensen Krige, "Girls' Puberty Songs and Their Relation to Fertility, Health, Morality, and Religion Among the Zulu," Africa: Journal of the International African Institute 38, no. 2 (1968): 173-198.
} 
Cobbing, J. “A Tainted Well. The Objectives, Historical Fantasies and Working Methods of James Stuart.” The Journal of Natal and Zulu History 6, (1988):115-154.

Cope, A.T. Ed. Izibongo: Zulu praise-poems. Oxford : Clarendon Press, 1968.

Golan, Daphna. Inventing Shaka: Using History in the Construction of Zulu Nationalism. Boulder: Lynne Rienner, 1994.

Guy, Jeff. The Maphumulo Rebellion: War, Law and Ritual in the Zulu Rebellion. Scotsville: University of KwaZulu-Natal Press, 2005.

Guy, Jeff. The View Across the River: Hariette Colenso and the Zulu Struggle Against Imperialism. Charlottesville: University Press of Virginia, 2002.

Hanretta, Sean. "Women, Marginality, and the Zulu State: Women's Institutions and Power in the Early Nineteenth Century." The Journal of African History 39, no. 3 (1998): 389-415.

Hamilton, Carolyn. "Backstory, Biography, and the Life of the James Stuart Archive." History in Africa 31 (2011): 319-341.

Hamilton, Carolyn. Terrific Majesty: The Powers of Shaka Zulu and the Limits of Historical Invention. Cambridge, Mass: Harvard University Press, 1998.

Krige, Eileen Jensen. "Girls' Puberty Songs and Their Relation to Fertility, Health, Morality, and Religion Among the Zulu.” Africa: Journal of the International African Institute 38, no. 2 (1968): 173-198.

Kuper, Adam. "The 'House' and Zulu Political Structure in the Nineteenth Century." The Journal of African History 34, no. 3 (1993): 469-487.

Kuper, Adam. "Symbolic Dimensions of the Southern Bantu Homestead.” Africa: Journal of the International African Institute 50, no. 1 (1980): 8-23.

Laband, John. The Rise \& Fall of the Zulu Nation. London: Arms and Armour Press, 1997.

Magogo KaDinuzulu, Constance, Ed. Hugh Tracey. "The Zulu Songs of Princess Constance Magogo KaDinuzulu.” Series: Music of Africa Series 37. Grahamstown, South Africa: International Library of African Music).

Malcolm, D. Mck. “Obituary.” African Studies 12, no. 3 (1953): 131-132.

Masuku, Norma. "The depiction of Mkabayi: A Review of her Praise Poem." South African Journal of African Language 29, no. 2 (2009): 121-130.

Ndlovu, Sifiso. “A Reassessment of Women's Power in the Zulu Kingdom.” In Zulu Identities: Being Zulu, Past and Present, edited by Benedict Carton, John Laband, and Jabulani Sithole. New York: Columbia University Press, 2009: 111-121. 
Rycroft, David K. "A Royal Account of Music in Zulu Life with Translation, Annotation, and Musical Transcription." Bulletin of the School of Oriental and African Studies, University of London 38, no. 2 (1975): 351-402.

Tallie, T. J. "Queering Natal: Settler Logics and the Disruptive Challenge of Zulu Polygamy." Journal of Lesbian and Gay Studies 19, no. 2 (2013): 167-189.

Weir, Jennifer. "Chiefly Women and Women's Leadership in Pre-Colonial South Africa." In Women in South African History, edited by Nomboniso Gasa. Cape Town: HSRC Press, 2007: 3-20.

Weir, Jennifer. "I Shall Need to Use Her to Rule: The Power of 'Royal' Zulu Women in PreColonial Zululand.” South African Historical Journal 43 (2000): 3-23.

Wright, John. “A.T. Bryant and the 'Lala'.” Journal of Southern African Studies 38, no. 2 (2012): 355-368.

Wylie, Dan. Savage Delight White Myths of Shaka. Pietermaritzburg: University of Natal Press, 2000. 